\title{
THE INFLUENCE OF ACCEIERATED ROTATION ON HEMOGRAM
}

\author{
By \\ S. YAMAUCH[ \\ From the Department of Oto-Rhino-Laryngology, School of Medicine
Osaka University (Director: Prof. T. Hasegaua)
}

The influence of labyrinthine stimulation by accelerated rotation on the hemogram was observed in the dogs by means of Prof. Hasegawas ancelerating rotation apparatus, and the effect of sodium bicarbonate solution was also observed.

The results were as follows:

1) In the normal dogs, after subjected to uontinuous stimulation for 15,30 and 60 minutes, no chang: in the blood cell count was noted, but the chang in the differentiol leucocyte count was noted; re!ative lymphocytosis was noted temporarily, neutrophils were rather decreased, and there was no change in eosinophil and monosyte count.

2) Bilaterally labyrinthectomized dogs showed almost no change in hemogram, irrespective to the length of the stimulation.

3) Normal dog; previoosly treated with $2 \mathrm{cc} / \mathrm{kg}$ of $7 \%$ sodium bicarbonate solution also remained unaffected, notwithstanding continuous subjection to the rotatory acceleration.

4) In this experiment, the change in differential leiucocyle count, as the result of the accelerating stmuli, was interpreted as a phenomenon of sympatheticotonic reaction through the labyrinth.

It was especially pointed out that this effect of the labyrinthine stimulation could be prevented by the injection of sodium bicarbonate.

\section{加速趈転刺戟の血液像に及ぼす影響}

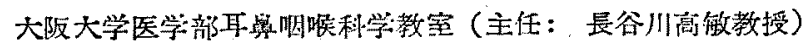

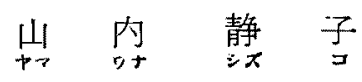

目次

1. 緕㝘

2. 交献的洘察

3. 実跨方法

4. 実驗成綕

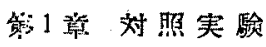

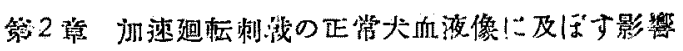

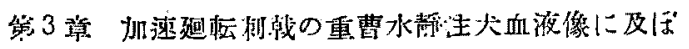
与影䊝.

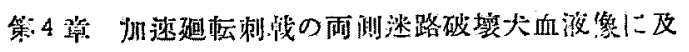
王与影殷

\section{5, 総括及び溥览}

6. 結 諵

7. 答考交献

\begin{abstract}
緒 言
乗物の醉に刘しては古来多くの人々が悩まされてきた が, 近来めざ志しい交通機関の発逆に征つて航空病, 船 量，事最等保物刀醉刀著しい増加がみられる。これは主 に乘物の動摇に際し，内耳耳石に加速度刺㦸が加わり生

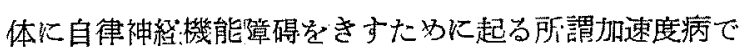
步ると云ら事が長谷川教授により明らかにされ，その甬

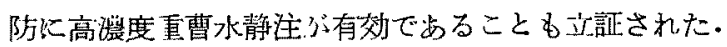

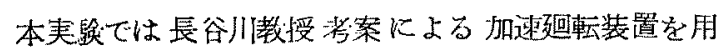

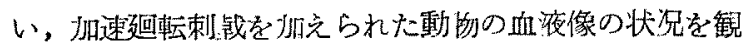
祭し，次いで高㜔度重曹水静注を行つた動物の血液像を 検直して，その成績を比較検討した。
\end{abstract}

\section{文献的考察}

船灵，東最，航空病等加速度を伴う動摇に上る乗物の 
酥に関する記述は，古く Hippokrates $3 か$ 船最は身体の 摫乱せられた状態であるという記録に始まる・この動摇 がいかにして所謂「乘物の醉」を起すかについては19世 紀以後連々な説が挙げられた。即ら恐㳍説，中毒説，視 党説, 内臟振蕰説, 中枢神経障碍説, 平衡障碍説等であ るが、いずれる憶湘にすぎなかつた・これらの5ち Pollard (1872), Carpenter, Abrahamsz (1874) は迷路 刺㦸火よる平衡障碍説を唱光内耳の意義を重視した。次 いで Flourens (1824) は身体平衡と迷路の関係につい

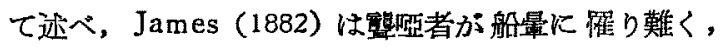
Reynold (1884) は化膿性内耳炎を経過した者は屡々船 最を免れたことを報告した・1902 年 Kreidl は両側聴 神経:切断あるいは両側迷路を剔出した犬では船最を起さ 绵とと報告し，船最と迷路との関係が初めて実験的に 証明された・亦 Bàràny（1910）は前庭刺战症状と船量 とは類似して挌り，船最は内耳の異常刺㦸炕よつて綉発 されると述べたこと等，迷路刺㦸を迴つて多くの実験 がなされたが，その結果恃必ずしも一致しなかつた。こ れに対し，長谷川教授並びに協同研究者等は連緬景降

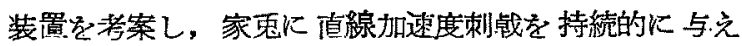
いかなる現象がいかにして起るかを観察し，常に一定し た成績を得ることができた・即ち迷路に対する加速度刺 战が交感神経の緊張をきたして自律神経機能刀障碍によ り新陳代謝障碍を起すことを，血圧，血液つ諸性状，体

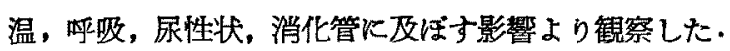
而してこの病態詨し加速度病 (Acceleration Dis-

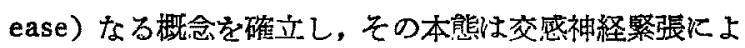
る自律神経機能障碍であると述べられている。連続戒降 装置による加速度迷路刺镈の実娩として遠藤 (1940) は 迷路性つ体温下降学，古川（林）(1941）は呼吸扣制,7 高井 (1943) は血圧の上昇を報告した. 又消化器系に括 いて柴田（1943）は迷路刺战による胃腸運動坜制，大川 内 (勝) (1951) は迷路性㗐吐の実験で幽門の䇣緛, 噴 門つ弛緩，腹圧及び胃内圧の上昇，胃運動つ抑制と胃下 ーヌスの娍退を認め，本現象が交感神経緊張性であるこ とを明らかにした・そつ他㲾について前田（豊）(1944） は加速度刺㦸により尿量の減少, 比重の增加, 総空素量 の増加, クレアチン, クレアチニン量の増加を認めるこ とを報告した：又血液に与党る変化汇関して，古川（隆） （1937）《迷路性のリンパ球減少，遠藤（1940）は血漿 のアルカローヂス, 血梼の著增, 赤血球沈降速度のやや 促進するのを認め，伊東 (1943) は血獎カルシウム量つ

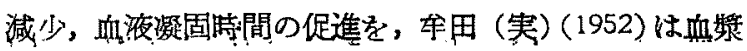

蛋白の增加及びア・グ比の上算学報告した. 次に Best

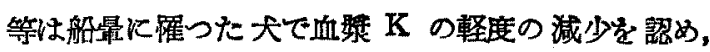
Fields 等は正常人について, 動摇刺㦸後最の発現いか ん飞拘らず血梼增加，血液燐の減少を認め， $\mathrm{Ca}, \mathrm{K}, \mathrm{Na}$ 等の血液成分には有意の变化をみなからた。

某他迷路刺战による自律神䅅への影響として Spieg. el, u. Demetriades (1922) は家鬼に括いて迴転, 冷 温, 電気刺战を行い，血圧の下降を，吉田（璋）(1927） は, 刺战つ弱、場合には血圧下降又は犁降の变動を, 強 刺战の場合は常に上算することを報告した。久保 (1935) は肝㽞の色素排泄機能は迷路刺战に上り色素排泄の遅延 するのを認めた・文小西 (1949) は家鬼で迷路刺㦸によ る脳循環の減少, 末梢循環の堌加, 門脈系統の充血, 腎 臟循環の増加を認めた。

な技，前庭迷路の刺战感受部位については古来 MachBreuer の仮説が信しられ，位置の変化と直楾運動は前

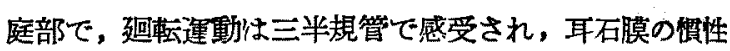
によるずれ及び半規管流動が原因とされてきた。これを 実験的に証明しょうとして Magnus 及び de Kleyn （1921）はモルモットを用い，Wittmaack の遠心咂転 法により耳石膜を剝離し，位置の变化は前庭部で，延転 及び直楾運動は共に三半規管で感受されると発表した。 これに対し，長谷川教授（1931）は彼等の実験の讙謬を あけ゚，三半規管で感受されるのは迴転運動のみであり， 直楾運動は前庭の耳石器管で感受されることを㬰驗的似 決定し，更に位置の变化は内淋巴の静水王炕よることを 明らかにした文加速度病に打いては加速底刺㦸が主とし て内耳の耳石に作用し交感神経緊張性の自律神経機能失 調を起すことを明かにした一方乗物の醉即ら加速度病の 予防として古来全くなす所なく，僅かに中枢麻焼削服 用に頼つていたが近来長谷川教授は $7 \%$ 重曹水の静胍内 注射が耳石に变化を及济し，迷路の加速度刺幟以対する 感受性を減弱せしめることにより加速度病つ発生を予防 し得ることを創案された・藤崎 (1947) が474名の兵士 につき輝かしい成果を収め又，豊島 (1950)，龺田（哲） (1950) 等により追試され満足すべき絬果が報告された. 一方1949年アメリカニ出いてドラマミンが船最の予防 並びに治療に有效なことが, Leslie N. Gay によって 報告され世人の注目をひいたが本薬の船最の予防の作用 機転については解明されていない。

「さて以上の上らに加速度を伴う動䍃の迷路刺战が交感 神経緊張性の自律神経機能不全を起すのであるが,この 自律神程と血液そが密接な叞係のあることは周知のこと 
である、迷路刺戟と血液像との閦係については能述の他

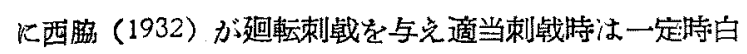
血球减少，多核白血球の増加をみるが過剩束战では全く これと相反する結:果を得たと述べている。

\section{実 篤方 法}

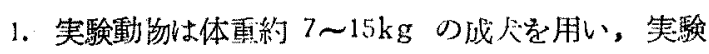
前外丮道に異物なく鼓膘の正常なこと，改び迷路反射 K異常のない事を确めた。性は考慮しなかつたが，娃 桭，授乳中つ雌大及び病犬は除外した。更に努めて騒 音，移転等による精神的慟䍃を避けるょう留意し，実騟 は戦寒，炎暑の候をさけ，等温は $15^{\circ} \mathrm{C} \sim 30^{\circ} \mathrm{C}$ で可攻

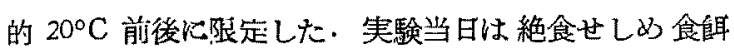
による変動を努めてさけるようにした。

2. 犬に加えた手術的操作は総て無菌的に行った。痛 覚刺皒による影響をさけるためにェビパン・テトリらム を $1 \mathrm{cc}$ 中 $0.1 \mathrm{gm}$ 溶解した水溶液を大凡 pro-kg 0.5cc

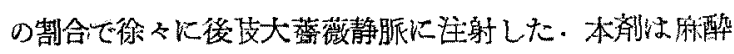
郕か中で最も副攸用少なく，血圧，新䠅代㛛等に対して も殆んど影響がない等つ理由でこれる使用した。

迷路破裁：迷路破壊には耳翼附着部より皮属切開を加 え，耳翼を前方に和しやり，外耳道軟骨部を切開し，続 いて骨部外联道を経て鼓膜に羍しこれを破って鼓室を開 放し棈円空，鼓室岬を明視し次いで小鋭匙で棈円空より

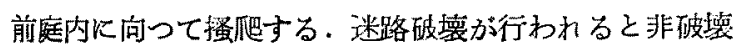

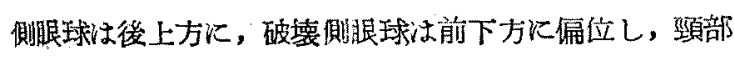
は破壊則を下にして捻䎐し，四肢は破壊則では屈曲内

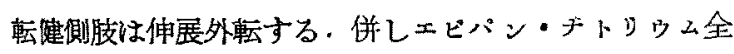
身麻醉のために眠震は観察され難い、続いて速やかに反

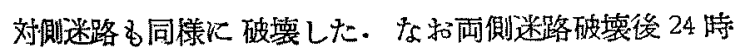
間を経て実鈳に供した。

3. 重曹注射： $7 \%$ 重曹水 pro-kg 2cc の割合で各

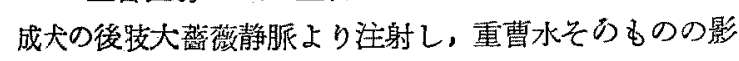
響をさけるため注射挠少なくとも2 日上上を経た動汤で 実歌を行つた。

4.アドレナリン注射：体重 $10 \mathrm{~kg}$ Kつきアドレタ リン $0.13 \mathrm{mg}(0.1 \%$ 塩酸エビレナミン $0.13 \mathrm{cc})$ を皮下 飞注射した.

5. 動物の固定：犬の固定は呬転板上に装置した固 定台上飞背位に，且つその体軸が迎転板の直径に一致 し，頭部を外側にむけて四肢を䋈縛し，次に頭部る固定 し，迴耺による傿幹振動を可及的に防ぐために腹部を軽 く固縛した.

6. 採血法：副督静脈が下大静脈に注ぐ部を中心と
して下大静脈の上下を結紮し榇血する Stewart 及び Rogoff $(1916 ， 1917)$ の所謂 Cava-Pocket 法になら

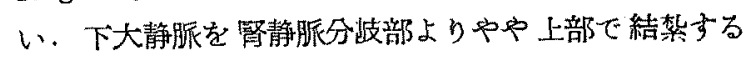
Cava-Pocket 变法を朋い，その㵔溜血液を採血するなj

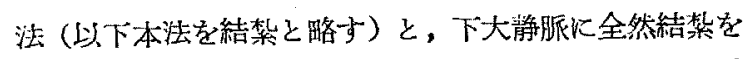
行わずに採血する方法（以下盤結禁と略す）故び股静脈 上りの採血とを行つた．以上の万法て刺钱前，刺战後持 間毎 (刺战直後, 10 分後, 30 分後, 60 分後及び 90 分後) に每回採血し，その血液像を観察した・

7. 加速超転装犆：加速廻転刺战を加えるため長

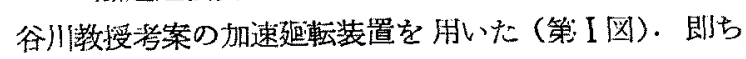
モーター（M）の迴轻により,ベルトで連結された各プ

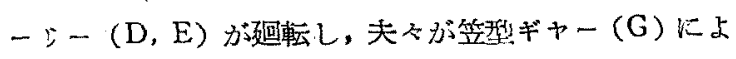
りシャフト(F) の迴轱となり次いでその一端に装置さ れた腕 (A，C）の運動を変り，更に腕 (C) の附着与 る円板 (B) の往復廷転運動となつて現われる・即ちた ーター (M) の迴転を敏分 45, 60,90回の3 段にするこ

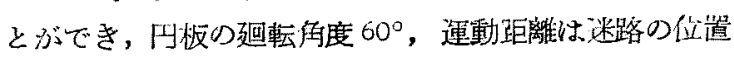
では約 $60 \mathrm{~cm}$ で，本装埴ではブランコ運動を水平面比 描かせる。つまり従来の迴転運動では見られなかつだ往 復迴転運動を営さ上K，廹転方向及び加速度が絶えず持
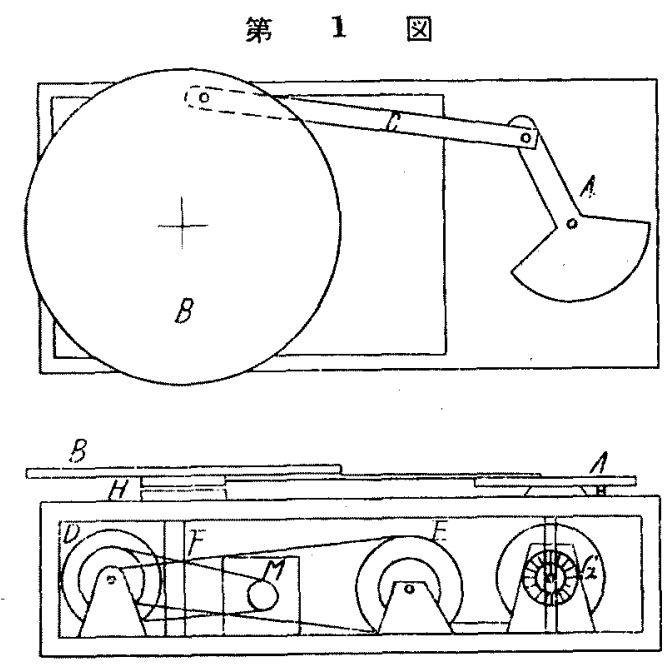

$$
\begin{aligned}
& M ; モ-g-\quad E ; 7^{\circ} \text { リ- } \\
& A, C \text {; 腕 } F \text {; シャ가 } \\
& B \text {; 角加速度板 } \quad \text { G；笠型ギャー }
\end{aligned}
$$

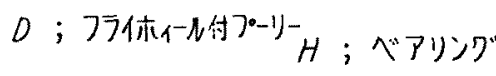$$
1 \quad m
$$ 
続的に変化するようになつて括り，長持間に亘つて廷転

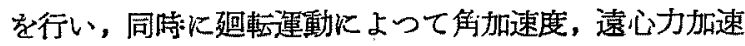
度刺㦸の影響をる検討することができる。即ら本装置は 加速度発生の点に和いては従来の䛜転装置と甚だ趣を異 にしている。

8. 血液㭘查. 血色素算定法：ザーリー氏血色素計 を朋いた，血液を吸血ビペットにて20立ゔ粍吸入し， 10 の度感迄 $0.5 \%$ の塩酸溶液を入れた小管中に吹き出 しょく混和し，10 分後に標潐管の色と比色する。

赤血球計算法：トーマ・ッアイスの計算器老用いた。 赤血球混和用ピペットの毛緛管中 0.5 の標記の所迄血液 を正確に吸い，更に稀採夜（ハ1ェム民液）を101 の目 盛迄吸 弓. 即ち血液は 200 倍江稀积される．次にピベッ 卜を充分（約 100 回）振盪混和する・最初の 2 3 滴を捨 てた後一小筒を計算盤の中央汇怙きニニートンリングの 生ずるよらにデッキ硝子で被い，その小区劃 80 内の血

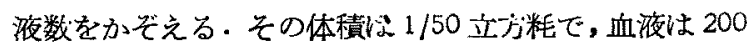
倍に稀勫されているから，得た価を10，000倍したもの が 1 立ゔ粍中の赤血球数である。

白血球計算法：トーマ・ッアイスの計算器を用いた。 白血球混和用ピペットを用いその目盛 1 迄血夜を吸い， 稀釈液（チニルク氏液）を䅺記 11 迄吸引・即ち血液は 10 倍沉稀积される・ピペットを充分桭邊混和し赤血球の場 合と同様鏡倹し，計算室全ての区劃内つ白血球を数え る.全区劏は $1 / 10$ 立方粍であり，血液は10倍に稀釈さ れているから 1 立方粍妕の血球数は得た洒を 100 倍す ればよい。

白血球百分率：無水アルコール，エーテルで充分脱

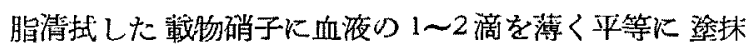
し，急速に乾懆させる。次いで染色はギム斗染色を行つ た. 即ちメターール内に 1 2 分投入固定し, 乾懆後溜 水 $1 \mathrm{cc}$ に対しギムザ夜 2 榈の割合で稀釈した染色液で 15〜20 分染色後，水洗乾燥して鏡検した.

\section{第 1 章 対照実験}

\section{実 験 成 績}

実験目的のための刘照実験として，血液像に対する採 血の影響， $7 \%$ 重曹水静注，アドレナリン注射の影響を みた。

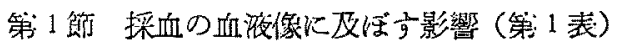

小括：正常犬にエビパン・ナトリウム静注の上固定 台比固縛L，固縛前，固縛值後，10 分，30 分，60 分及 び 90 分後の血液像を検した。採血はNo.23 は結禁， No. 36 は股静脈より行つた。
第I表 探血の影望

\begin{tabular}{|c|c|c|c|c|c|c|}
\hline & & & & & & \\
\hline & 固定前 & 龺 樈 & 10分復 & 30 分供 & 60 分媛 & $90 \pi$ \\
\hline 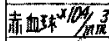 & 489 & 488 & 491 & 480 & 485 & 481 \\
\hline 白血球 $/ 4 \pi^{3}$ & 8000 & 8000 & 7800 & 8000 & 8200 & 7800 \\
\hline 奥先青\% & 78 & 78 & 79 & 78 & 77 & 77 \\
\hline 白待中球 & 65 & 6.3 & 64.5 & 64 & 60.5 & 63 \\
\hline 息狈酸球 & 0 & 2 & 1.5 & 1 & 1.5 & 0 \\
\hline 球獂基球 & 0 & 0 & 0 & 0 & 0 & 0 \\
\hline 炃覃球 & 8 & 10 & 7 & 8 & 8.5 & 8 \\
\hline 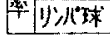 & 27 & 25 & 27 & 27 & 29.5 & 29 \\
\hline
\end{tabular}

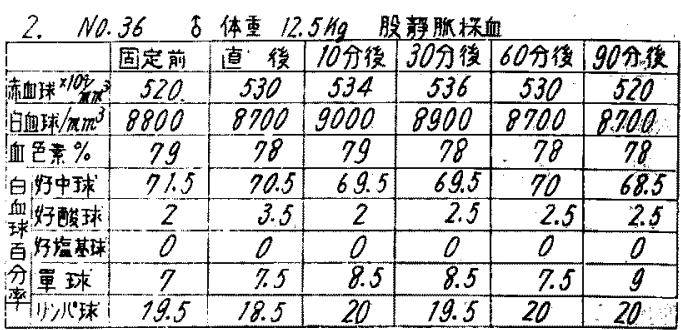

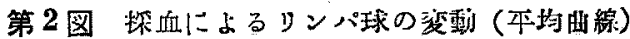

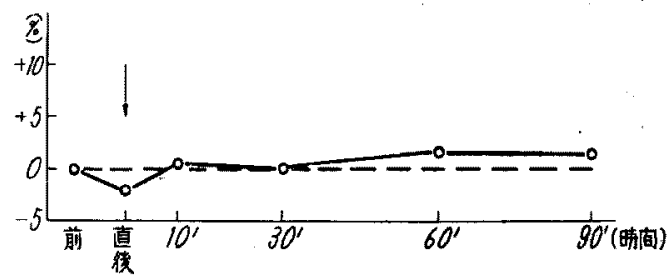

赤血球数，白血球数，血色点量についてはいずれると の動摇は僅少で誤美の範囲内にあるとみられる・好中球 飞招いては No. 2.3 で 60 分後に $4.5 \%$ 減少，No. 36 で 90 分後に $3 \%$ の減少を示しその他怯全般に 1 2\% の葴 少を示すに過ぎない，好酸球では No. 23 で直後に $2 \%$ 增加，No. 36 で直後 $1.5 \%$ 增加が最大で認むべき变化 なく，単球も2〜0.5\%の堌減あるのみである.リンパ 球汢第: 2 図の如くその平坛值は（以下平均曹線はりンバ 球つ傥長を示す.) 直後 $1.5 \%$ 減少，10 分後 $0.25 \%$ 增 加，30 分後は変らず， 10 分後 $1.5 \% ， 90$ 分後 $1.25 \%$ 增 加とやはり䚀明な变化を示さなかつた．即ち採血によっ て血液像儿は殆んど影響はなかつたとみられる。

\section{第: 2 節 $7 \%$ 重曹水注射の血液像に及佂す} 影響（第: II表）

小括： $7 \%$ 重曹水 $2 \mathrm{cc} / \mathrm{kg}$ の割合で 後技大蕾薇静脈 に注射し，下大静脈を結紮なず 2 例火ついて注射前; 淔 㣞，10分後，30 分後，60分後に採血し鹳察した．赤血 球数恃 2 列共畒しい变化はなく，白血球数は No.53、て は60 分後に 1400 の増加をみるがその他にば者明な变化 を示さなかった。血色素量は No. 53 は30分後最大で 
第 II 表 $7 \%$ 重曹水注射の影䓦

\begin{tabular}{|c|c|c|c|c|c|c|}
\hline & 注射牙 & 佳的直说 & 10万人 & 30八位 & 60分徍 & 90分场 \\
\hline & 368 & 347 & 321 & 320 & 373 & 313 \\
\hline & 9000 & 9200 & 9400 & 9200 & 10400 & 9500 \\
\hline & 78 & 76 & 78 & 75 & 76 & 76 \\
\hline & 71 & 70.5 & 71.5 & 71.5 & 69 & 72.5 \\
\hline & 4.5 & 5.5 & 5.5 & 4 & 4 & 5.5 \\
\hline 整球 & 0 & 0 & 0 & 0 & 0 & 0 \\
\hline & 6.5 & 6.5 & 5.5 & 6.5 & 5 & 7 \\
\hline 双棵 & 18 & 17.5 & 77.5 & 18 & 22 & 15 \\
\hline
\end{tabular}

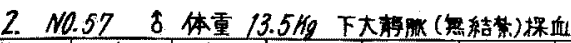

\begin{tabular}{|c|c|c|c|c|c|c|}
\hline & 注射前 & 注射直俊 & 10 分復 & 30分得 & 60 分援 & 90分铰 \\
\hline tolat & 502 & 506 & 508 & 508 & $5 / 4$ & 505 \\
\hline (m) & 7300 & 7400 & 7450 & 7150 & 7000 & 7200 \\
\hline 血点 \% & 82 & 87 & 80 & 80 & 80 & 81 \\
\hline 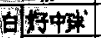 & 63 & 68.5 & 69. & 70 & 70 & 67.5 \\
\hline 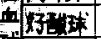 & 4 & 4.5 & 3.5 & 1.5 & 3 & 49 \\
\hline 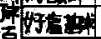 & 0 & 0 & 0 & 0 & 0 & 0 \\
\hline 贫 7 球 & 4 & 3.5 & 5 & 5.5 & 3 & 4.5 \\
\hline 4 J & 29 & 23.5 & 22 & 23 & 24 & $24-$ \\
\hline
\end{tabular}

第 3 図 重曹注射によるワンバ球の変動 (平均曲線)

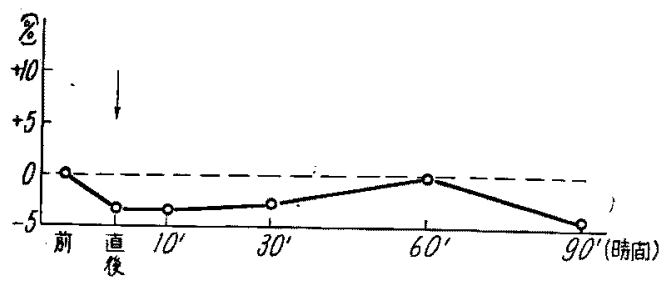

\%減少，No. 57 では最大 $1 \%$ の減少を示す。好中球で はNo. 53 で 60 分後に 2\%減少し传は殆えど変らず， No. 57 では軽度の増加あり，好酸球，単球では認むべき 動摇なく、リンパ球は No. 53 は 30 分後まで殆んど変 らず，60 分後に中や增加し (4\%) 90 分後では却って娍 少している. No. 57 では直後より全般に 5〜7\% の娍少 をみ，平均值では直後と 10 分後とに $3,5 \% ， 30$ 分後に $3 \%$ の減少，60 分後で殆んど元に復し 90 分後で再び 4 \%の淢少を示した（第3図）。

第3節 アドレナリン注射の血液像に

\section{及仿す影響（第血表）}

小括： $0.1 \%$ 塩酸エピレナミン液を体重 $10 \mathrm{~kg}$ につき $0.13 \mathrm{cc}$ の割合で皮下注射し，2 例について股静脈より採 血し, 注射前, 直後, 30 分後, 60 分後の血液像を観察 した. 赤血球数, 白血球数, 血色素量では著しい変化は 丞られず，白血球百分祭では好中球は直後に No.61で 18\%減少, No.62 で 10.5\%の減少，10 分後で 5 及 び $5.5 \%$ 減少，その後は殆んぞ前值に戻つている．好酸 球単球では $1 \%$ 前後力増減を示したに過ぎない。リンパ
第III表 アドレナリン注射の影制

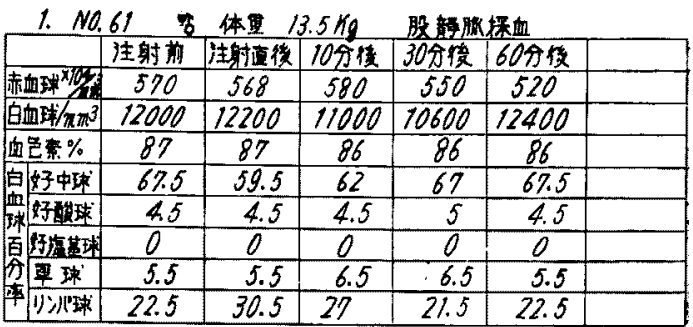

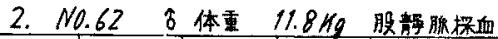

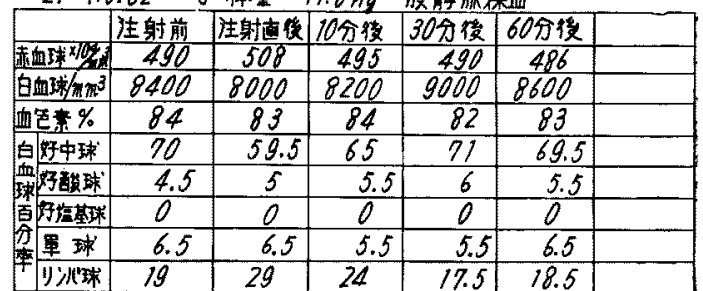

第4图 フドレナリン注射によるリンバ球 の変動 (平均曲線)

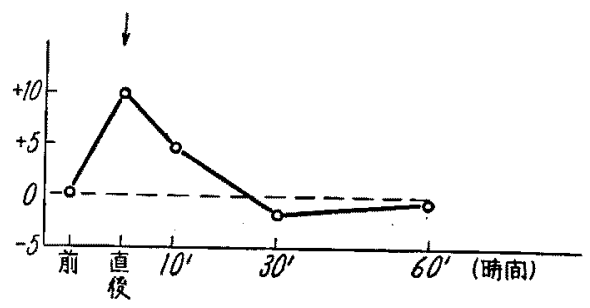

球は No. 61 では直後に $8 \%, 10$ 分後 $4.5 \%$ 增加, No. 62 では直後に $10 \%, 10$ 分後 5\%堌加, その後は惊注注射 前の価となる、平坛值では，直後 $9 \% ， 10$ 分後 $4.25 \%$ 増加， 30 分後 $1.25 \% ， 60$ 分後 $0.25 \%$ 減少となる（第 4 図).

第 2 章 加速迴転剌韩の正常犬血液像に 及ばす影響

第 1 節 15 分間加速迴転刺㦸の正常大血液 像に及守す影響（第:IV表）

小括：採血は No.40，No.47 は下大静脈より結染せ すと，No. 44 は股静脈より行った・赤血球数は No. 44

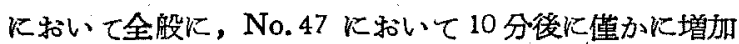
しているが他は僅かに減少し，白血球はNo. 40 の直後 及び 90 分後でやや堌加をみるが著明な変動は認め難い. 血色素量は各々最大 $2 \%$ の増減を示し，全例に 30 分以 後慬が減少の傾向がある。白血球百分率に扎いて好 中球は No. 40 では 10 分後より潮次堌加, 60 分後最高 で 8\% 堌加し，No. 44 では 10 分後， 30 分後に減少し 
第 IV 表 正常犬 15 分制戟の影響

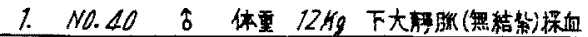

\begin{tabular}{|c|c|c|c|c|c|c|}
\hline & 耕棹前 & 刺戟直俊 & 10 分後 & 30命练 & 60分後 & 90分媵 \\
\hline 竟理球观 & 566 & 550 & 501 & 559 & 538 & 540 \\
\hline$\theta \mathrm{H}$ & 9600 & 11000 & 10900 & 104000 & 10100 & 11000 \\
\hline 进邑素％ & 77 & 77 & 76 & 76 & 76 & 76 \\
\hline 皇轱中球 & 64 & 63.5 & 66 & 59.5 & 72 & 70.5 \\
\hline 望 & 3 & 4 & 4.5 & 4.5 & 2.5 & 1.5 \\
\hline 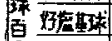 & 0 & 0 & 0 & 0 & 0 & 0 \\
\hline 忿單球 & 4 & 2.5 & 1.5 & 4 & 7.5 & 2 \\
\hline 平 准球 & 29 & 30 & 29 & 32 & 24 & 26 \\
\hline
\end{tabular}

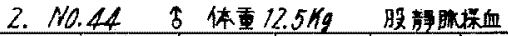

\begin{tabular}{|c|c|c|c|c|c|c|}
\hline & 刺戟前 & 刺敫面牧 & 100 轨 & $30 \pi 12$ & 6039 & 90分後 \\
\hline 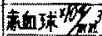 & 473 & 487 & 484 & 516 & 510 & 508 \\
\hline e血球 $/ 2 \pi^{3}$ & 9600 & 9400 & 10200 & 8800 & 9600 & 9000 \\
\hline 值先籴\% & 68 & 70 & 69 & 67 & 67 & 68 \\
\hline 白好中球 & 57.5 & 57 & 53 & 525 & 57 & 57 \\
\hline 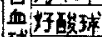 & 3 & 2.5 & 3.5 & 2 & 4 & 5 \\
\hline 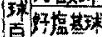 & 0 & 0 & 0 & 0 & 0 & 0 \\
\hline 鸽墅球 & 2 & 2 & 2 & 1.5 & 2.5 & 3.6 \\
\hline 本句以“球 & 37.5 & 38.5 & 41.5 & 41 & 36.5 & 34.5 \\
\hline
\end{tabular}

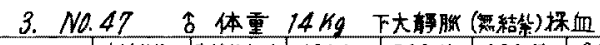

\begin{tabular}{|c|c|c|c|c|c|c|}
\hline & 刺韩前 & 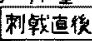 & 10分谈 & 30分镜 & 60分传 & 90分後 \\
\hline to球 $\times 10 \% 3$ & 479 & 441 & 498 & 478 & 475 & 480 \\
\hline Gno球/ $x^{3}$ & 11400 & 11200 & 11200 & 10800 & 11000 & 11400 \\
\hline 血喼 \% & 70 & 70 & 72 & 68 & 69 & 69 \\
\hline 白连子中球 & 74 & 64 & 58 & 52 & 58 & 61.5 \\
\hline 血球好酸球 & 4 & 5 & 4.5 & 5 & 4.5 & 5.5 \\
\hline 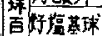 & 0 & 0 & 0 & 0 & $\theta$ & 0 \\
\hline 分覃球 & 4 & 4 & 2.5 & 4 & 4.5 & 4.5 \\
\hline 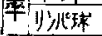 & 18 & 27 & 35 & 39 & 33 & 28.5 \\
\hline
\end{tabular}

第 5 図 正常犬 15 分制戟によるリンハ球 の变動（本均曲線）

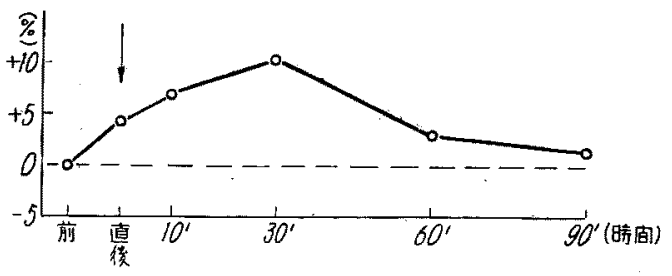

以後は元に復し，No.47では直後より娍少，20 分後 $22 \%$ 減少，以後僅か怩恢復の傾向を示す，好酸球の变 化は著明でない. 単球は No.40，47 の10 分後に減少 するが他の変化は一定しない，リンパ球は No.40，44 でやや増加, 60 分以後は却って娍少し, No.47 では直 後より著明に増加し 30 分で最高となり60 分以後は元に 復する傾向を示し，3 例の平均では 30 分後が 増加最大 である. 即ち直後 $3.6 \%, 10$ 分後 $7 \%, 30$ 分後 $10,1 \%$ ， 60 分後3\%，90 分後 1.1\% とそれぞれ増加している（第 5 图).

第 2 節 30 分間加速廻転刺战の正常大血液 像に及ぼす影響（第 $V$ 表）

小括： 棌血は No.35 は下大静脈より無結熊で, No.
第 $\mathbf{V}$ 表 正常大 30 分制戟の影

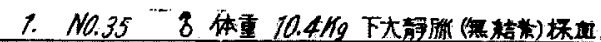

\begin{tabular}{|c|c|c|c|c|c|c|}
\hline & 刺钺前 & 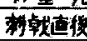 & 10 命 & 300 後 & 60 分政 & 90 分使 \\
\hline 赤的球N & 447 & 475 & 512 & 511 & 490 & 490 \\
\hline 血血球/ $/ 2 \pi$ & 8000 & 7900 & 8000 & 7600 & 7800 & 7400 \\
\hline 血邑素\% & 84 & 84 & 85 & 84 & 83 & 84 \\
\hline 白娃中理 & 75 & 66 & 61 & 65 & 63 & 65 \\
\hline 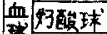 & 3 & 3 & 5 & 4 & 4 & 4 \\
\hline foteta & 0 & 0 & 0 & 0 & 0 & 0 \\
\hline 总球 & 2 & 3 & 2 & 4 & 4 & 4 \\
\hline 钢儿玻 & 20 & 28 & 32 & 27 & 29 & 27 \\
\hline
\end{tabular}

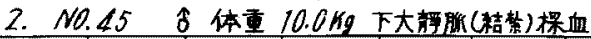

\begin{tabular}{|c|c|c|c|c|c|c|}
\hline & 刺载前 & 剌㦸直後 & 10 年桡 & 30分俊 & 60 分绖 & $90 \lambda$ 隐 \\
\hline 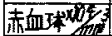 & 540 & 545 & 541 & 540 & 544 & 540 \\
\hline 自回球 $/ \pi \pi^{3}$ & 9200 & 11000 & 9400 & 9000 & 9300 & 9000 \\
\hline 血色紊\% & 78 & 79 & 78 & 78 & 77 & $7 \overline{7}$ \\
\hline 白好中球 & 74.5 & 62 & 60 & 66.5 & 69 & 69.5 \\
\hline 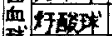 & 2 & 3 & 5 & 3.5 & 2 & 2.5 \\
\hline 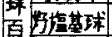 & 0 & 0 & $D$ & 0 & 0 & $\theta$ \\
\hline 害球 & 3 & 3 & 4.5 & 3 & 5 & 4 \\
\hline 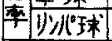 & 20.5 & 32 & 30.5 & 27 & 24 & 24 \\
\hline
\end{tabular}

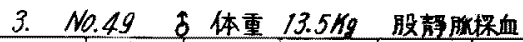

\begin{tabular}{|c|c|c|c|c|c|c|}
\hline & 刺戎前 & 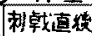 & 10 分役 & 30分後 & 60分彵 & $90 \mathrm{~A} 13$ \\
\hline 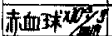 & 445 & 472 & 470 & 456 & 430 & 443 \\
\hline 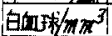 & 11200 & 12600 & 12800 & 10000 & 11400 & 11400 \\
\hline 血色亲\% & 76 & 74 & 70 & 72 & 73 & 73 \\
\hline 白好中球 & 70 & 71 & 63.5 & 53.5 & 69 & 70 \\
\hline 如好酸球 & 4 & 4 & 5 & 3 & 4 & \\
\hline 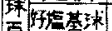 & 0 & 0 & 0 & 0 & 0 & $a$ \\
\hline 全军球 & 5 & 3 & 1 & 5 & 5 & 4 \\
\hline 辛乡儿球 & 27 & $2 Z$ & 30.5 & 38.5 & 22 & 23 \\
\hline
\end{tabular}

第 6 图正常犬 30 分制載によるУンバ球 の変動 (平均曲線)

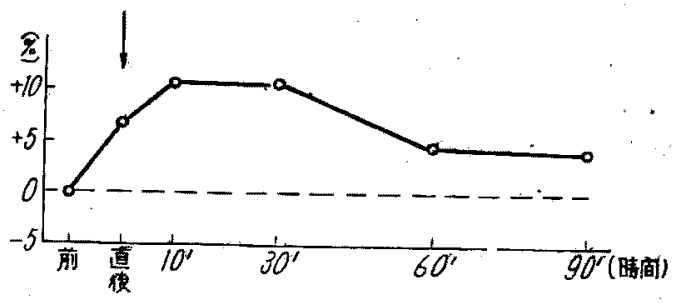

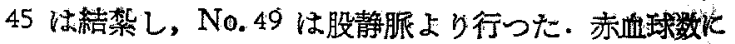
ついては No. 35 では直後上り軽度の増拁, No.45 て は殆んど変化なく，No.49 でもその動摇は僅少である. 白血球数は No. 35 飞扔いて 90 分後炕軽度㺂少, No. 45 で直後に中や堌加，No.49に执いては直後及び10 分後 に軽度の堌加を示すのみである. 血色素量忹 No.35て は殆んぞ動摇なく，No:45 では60 分以後飞 少しく減 少, No. 49 では直後上り減少している.好中球は3例其 直後より減少し10 分〜30 分後が最も著明で次第流光 復している，好酸球は 3 例共僅加火 10 分後に最大の增加 （1３\%）示す. 単球は No 49 て 10 分後に $4 \%$ の棫 少を示す以外㥩しい差異を認めない、リンハ球据いい 
て恃 Na.35 は直後より增加し 10 分後で頂点に達し後

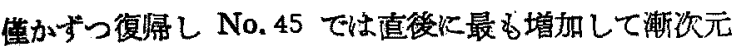
K戾り，No. 49 沬 30 分後は增加の最大を示し 60 分後 で急に殆んど元の価に復する. 即ち 3 例の平均值で沈， 直後 6.8\%，10 分後儿は $10.5 \%$ 增加で最多となり，30 分 後 $10.3 \%, 60$ 分後 $4.5 \% ， 90$ 分後 $4.1 \%$ 増加となる（第 6図):

第 3 節 60 分間加速迴転剌殘つ正常犬血液 像江及泟す影響（第U表）

小括：採血は下太静脈から No.31 は無結䅨で, No. 39 怡結紮し，No. 46 亿股静脈より行つた。赤血球数は No.31で僅かの減少を，他つ2例で僅かに增加を

第VI表 正常犬 60 分刺戟の影望

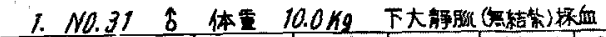

\begin{tabular}{|c|c|c|c|c|c|c|}
\hline & 刺钺前 & 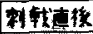 & 100传 & 30分後 & 60分传 & 90分信 \\
\hline 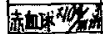 & 484 & 458 & 460 & 475 & 470 & 479 \\
\hline 白分球: $/ \mathrm{n}^{3}$ & 8400 & 8200 & 7600 & 8400 & 8200 & 8200 \\
\hline 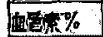 & 84 & 84 & 85 & 84 & 86 & 84 \\
\hline 白 烓中球 & 69 & 67 & 64 & 6.3 & 66 & 65.5 \\
\hline 6 抺磁球 & 2 & 2 & 3.5 & 4 & 4 & 3.5 \\
\hline 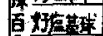 & 0 & 0 & 0 & 0 & 0 & 0 \\
\hline 盆更球 & 7 & 5 & 3.5 & 4.5 & 4 & 5.5 \\
\hline$=\frac{+51}{19 y}$ & 22 & 26 & 29 & 28.5 & 26 & 25.5 \\
\hline
\end{tabular}

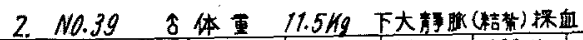

\begin{tabular}{|c|c|c|c|c|c|c|}
\hline & 刺戟前 & 剌钱屯得 & 10分牫 & 30 分䠧 & 60分㙅 & 90介伍 \\
\hline A & 496 & 490 & 508 & $5 / 2$ & 490 & 510 \\
\hline 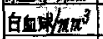 & 12800 & 10400 & 10200 & 9400 & 10000 & 9900 \\
\hline 血象係\% & 78 & 76 & 78 & 76 & 79 & 77 \\
\hline 香姆中球' & 75 & 67 & 10 & 68.5 & 73 & 70.5 \\
\hline 好球球 & 8 & 5 & 7 & 6.5 & 4 & 5.5 \\
\hline 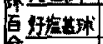 & 0 & 0 & 0 & 0 & 0 & 0 \\
\hline 金覃球 & 3 & 7 & 3 & 6 & 6 & 7 \\
\hline$f+\frac{1}{10}$ & 14 & 21 & 20 & 19 & 17 & 17 \\
\hline
\end{tabular}

\begin{tabular}{|c|c|c|c|c|c|c|}
\hline & & & & & & \\
\hline & 制钺前 & 利轨直得 & 10介後 & 30分復 & 60今 啳 & 90 伎 \\
\hline 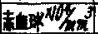 & 484 & 506 & 505 & 509 & 485 & 490 \\
\hline$n=1 / n m^{3}$ & 11200 & 11500 & 11400 & 8900 & 8000 & 8900 \\
\hline 色 $\%$ & 76 & 75 & 76 & 74 & 73 & 74 \\
\hline & 77 & 68.5 & 66.5 & 68.5 & 68.5 & 74 \\
\hline & 5.5 & 3.5 & 3.5 & 3.5 & 2 & 3.5 \\
\hline 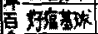 & 0 & 0 & 0 & 0 & 0 & 0 \\
\hline 等 & 6.5 & 4.5 & 3.5 & 3.5 & 4 & 4.5 \\
\hline 10 & & 23.5 & 26.5 & 24.5 & 25.5 & 18 \\
\hline
\end{tabular}

第 7 図正常犬 60 分制戴によるワン八球 の变唾（平均曲線）

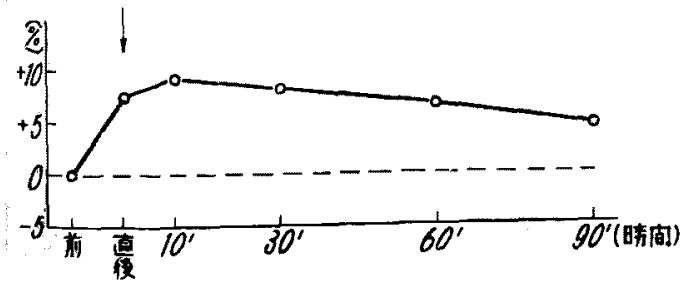

示し 60 分後には殆んど剌㦸前值に復し，誤巠範国を越 壳ていない. 白血球数は No. 31 の 10 分後及び No.39 の全没に減少し，No.46では30 分後にやや诚少してい る・血色素量には大きな变化はみられない，好中球は刺 战直後より減少している，好酸球，単球も若干の動摇を示 すが一定していない、リンバ球は全般に直後より增加し 且つNo.39,No.46では90 予後に殆んど元に復してい る. 即ち乞の平坛值は直後に $7,8 \%, 10$ 分後行最高 $9.2 \%$ 堌加となり，30 分後上り $8,3 \%, 60$ 分後 $6.8 \% ， 90$ 分後 には 4,5\% 増加と復帰の傾向をたどっている(第7 図).

\section{第 3 章 加速佪転刺戟の重曹注射犬血液像に} 及はす影響

$7 \%$ 重曹水を体重 $1 \mathrm{~kg}$ 当り $2 \mathrm{cc}$ の割合で実娩 2 日前 に大伕在静脈に注射したものにつき加速迴転刺战 15 分，

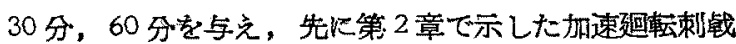
による正常犬血淮像の变動と比較し $7 \%$ 重曹水の加速迴 転刺敦抑制作用の有無即ち加速度病予防に有效か、否かを 血液像の面から検討した。

第: 1 節 15 分闇加速迴転刺戲の重曹注射犬 血淮像に及ぼす影響（第诃表）

小括：採血は No.33 は無結紮, No.48は結紮して

第 VII 表 重曾注射犬 15 分制戟の影巍

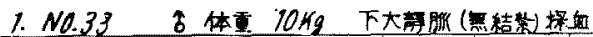

\begin{tabular}{|c|c|c|c|c|c|c|}
\hline & 刺钱前 & 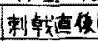 & 10分後 & $30 \hat{0}$ 後 & 60 \%得 & 90余俊 \\
\hline 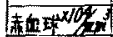 & 557 & 522 & 520 & 518 & 515 & 520 \\
\hline 白的球 $/ \pi \pi^{3}$ & 8400 & 8500 & 8000 & 8800 & 8800 & 8600 \\
\hline 血足竞 \% & 76 & 76 & 76 & 75 & 74 & 74 \\
\hline 传中球 & 74.5 & 75 & 97.5 & 78 & .75 & 76 \\
\hline 血稀酸球 & 2 & 3 & 3 & 2.5 & 2 & 1.5 \\
\hline 理旗基球 & 0 & 0 & 0 & 0 & 0 & 0 \\
\hline 皇覃 球 & 6.5 & 6 & 2 & 2 & 6 & 4.5 \\
\hline 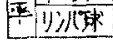 & 17 & 16 & 77.5 & 17.5 & 17 & 18 \\
\hline
\end{tabular}

\begin{tabular}{l} 
2. N0.48 \\
\hline
\end{tabular}

\begin{tabular}{|c|c|c|c|c|c|c|}
\hline 3. $N 0.5$ & 2 & 体重 & $.6 \mathrm{~kg}$ & 股解脈无 & 果血 & \\
\hline & 刺戟前 & 刺辣远找 & 10分後 & 3049 传 & 60分後 & 90 分 \\
\hline 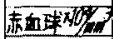 & 457 & 455 & 409 & 430 & 407 & 414 \\
\hline G宜球/ $/ \mathrm{mm}^{3}$ & 9200 & 9800 & 10600 & 10600 & 11000 & 9900 \\
\hline 边色 \% & 85 & 84 & 84 & 86 & 84 & 84 \\
\hline 白好中珓 & 79 & 78 & 775 & 77.5 & 83 & 78 \\
\hline 严 1 子酸球 & 4 & 4 & 4 & 3 & 7.5 & 4 \\
\hline 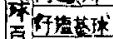 & 0 & 0 & 0 & 0 & 0 & 0 \\
\hline 㻎球 & 3 & 4.5 & 4.5 & 5 & 2.5 & 5 \\
\hline 准球 & 14 & 13.5 & 14.5 & 14.5 & 13 & 73 \\
\hline
\end{tabular}


第8図 重蕾泩射大 15 分制戟によるリンパ 球の变動（本均继線）

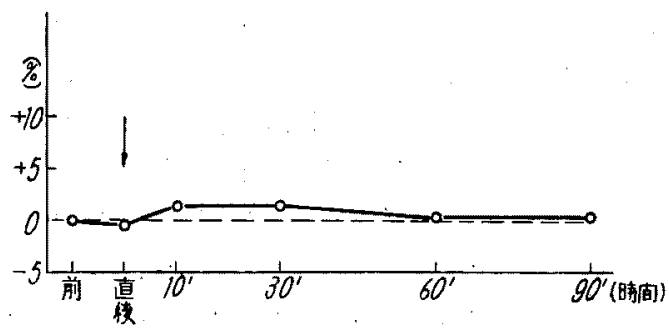

下大静脈か:ら，No. 52 は股静脈からら行つた。血球数は 3例共大した変動なく強いて云えば，赤血球は No. 33， No. 52 でやや減少，No.48 で 30 分後に僅かに增加 している. 白血球も No.33 の10 分後に蓬かに減少し その他は3例共少しく增加を示し，血色素量には殆んど 変化はない，好中球は No.33 は刺战後より次第に 増 加，60 分後では元に戾り，No. 48 ては 10 分後から軽 度の減少，No.52 ては極く僅かに城少しているが，た だ 60 分後に中や増加を示している. 好酸球は No.52 の 60 分後に減少与るがその他は殆んど 変動しない，単 球は No.33 の10分，30 分後に減少与るが他㤝らな い、リンパ球に竹いては3例共取りあげる程の变化は示

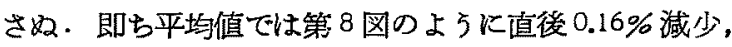
10 分後 $1.2 \%, 30$ 分後 $1.3 \%, 60$ 分後 $0.3 \%, 50$ 分後 0.16 \%の堌加を示すのみである(第8図).

第2 節 30 分盟加速廻転刺战の重啬注射犬

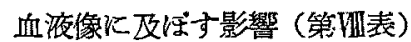

小括：採血は No.50 は下大静脈を結紮し，No.56

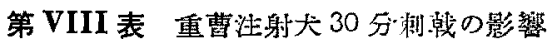

\begin{tabular}{|c|c|c|c|c|c|c|}
\hline NO. & 50 & 体重 & $0.5 \mathrm{~kg}$ & \multicolumn{3}{|c|}{ 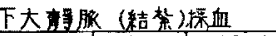 } \\
\hline & 嗔韩前 & 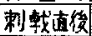 & 10 分情 & 30分模 & 60 分诖 & 90分啳 \\
\hline 赫血球 $\times 104$ & 395 & 388 & 430 & 412 & 408 & 376 \\
\hline 白滇球/ & 11900 & 12500 & 11400 & 11500 & 12800 & 12600 \\
\hline 血邑索 \% & 74 & 75 & 75 & .74 & 74 & 76 \\
\hline 白好中球 & 69 & 70 & 77.5 & 27.5 & 67 & 72 \\
\hline 血好酸球 & 3 & 3.5 & 1.5 & 1 & 4 & 7 \\
\hline 百好㘯基球 & 0 & 0 & 0 & 0 & 0 & 0 \\
\hline 分覃球 & 3 & 2.5 & 2 & 2.5 & 5 & 2 \\
\hline 利准球 & 25 & 24 & 25 & 25 & 24 & 25 \\
\hline
\end{tabular}

2. No 56 古体重 $8.5 \mathrm{Kg}$ 股静豚棉血

\begin{tabular}{|c|c|c|c|c|c|c|}
\hline & 刺韩前 & 蕀軲直传 & 10分復 & 30 分偻 & 60 後 & 90分後 \\
\hline 赤血球观名 & 506 & 506 & 502 & 507 & 492 & 488 \\
\hline 日血球 $7 x$ & 12200 & 12000 & 12400 & 12800 & 12800 & 12400 \\
\hline 血邑素 \% & 88 & 87 & 87 & 88 & 86 & 86 \\
\hline 白好中球 & 75 & 74 & 74 & 71 & 70.5 & 74 \\
\hline 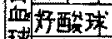 & 1 & 7.5 & 2 & 3 & 2 & 2 \\
\hline 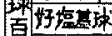 & 0 & 0 & 0 & 0 & 0 & 0 \\
\hline 分睪 珠 & 6 & 6.5 & 8 & 6 & 8 & 8 \\
\hline 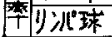 & 18 & 18 & 16 & 20 & 19.5 & 16 \\
\hline
\end{tabular}

第9图重曹注射夫 30 分剌戟によるリンハ球 の枍露（平均曲線）

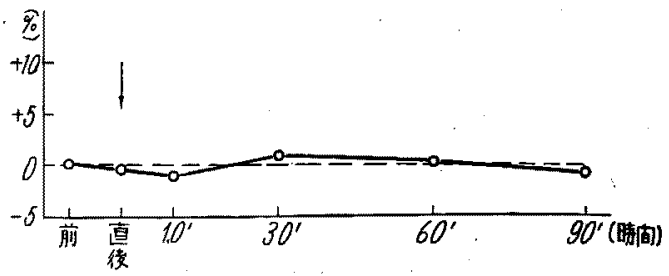

は股静脈より行つた・血球数には著明な変動はみられな W. 赤血球数は No. 50 で10 分後に増加し次策に元K 厣り，90 分後では却って僅かに減少, No. 56 ては 60 分，90 分後に僅汃減少している. 白血球数は No. 50 は直後， 60 分，90 分後に 400 900 増加，10 分，30 分 後では 500 400 減少, No. 56 では 10 分後上り 200 600 増加している．血色素量には殆んど变化はみられな い. 好中球は，No. 50 で 60 分後に僅かに減少，その他 は極めて僅加增加し，No.56 では 30 分，60 分後火 やや減少する以外は変化は殆んどみられない，好酸球性 No. 50 は 10 分, 30 分, 90 分後に 1.5 2\%減少, No. 56 ては一般に極く僅か（0.5〜2\%） の増加を示す. 革 球の墱減は僅少且つ不定である・リンパ球は最高 $2 \%$ の 变動で，平均值で第 9 図の如く，直後 $0.5 \% ， 10$ 分後 1 \%減少，30 分後 $1 \% ， 60$ 分後0,25\%堌加，90 分後 $1 \%$ の減少をみる。

第 3 節 60 分間加速廻転剌战の重曹注射犬 血液像に及注す影響（第区表）

小括：採血は No. 43 は下大静脈を結皆し，No.55

第 IX 表 重曹注射犬 60 分制戟の影響

\begin{tabular}{|c|c|c|c|c|c|c|}
\hline NO. & 13 年 & 体重 1 & $3.0 \mathrm{Kg}$ & 下大婙 & 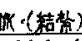 & 果面 \\
\hline & 刺戟前 & 吝戟直徐 & 10 分得 & 30 分 & 60 分传 & 90介次 \\
\hline 40 & 525 & 507 & 500 & 536 & 552 & 550 \\
\hline 血球 $/ \mathrm{m}$ & 8700 & 8500 & 9200 & 8700 & 8900 & 8700 \\
\hline 血它系\% & 79 & 78 & 77 & 79 & 78 & 70 \\
\hline 白行中球 & 81.5 & 76.5 & 76 & 75 & 80 & 75.5 \\
\hline 血好酸球 & 2 & 7 & 6 & 6 & 3 & 4 \\
\hline 标场基球 & 0 & 0 & 0 & 0 & 0 & 0 \\
\hline 球 & 4 & 4.5 & 6 & 4 & 3 & 6 \\
\hline 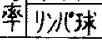 & 12.5 & 12 & 12 & 75 & 14 & 14.5 \\
\hline
\end{tabular}

\begin{tabular}{|c|c|c|c|c|c|c|}
\hline 2. No.S & & 体重 & $11.3 \mathrm{~kg}$ & 殿青承 & 胘枳血 & \\
\hline & 刺㦸前 & 副戟直俊 & 10 分後 & 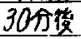 & 60分镜 & 90分供 \\
\hline 赤血球难 & 360 & 326 & 367 & 394 & 346 & 356 \\
\hline 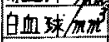 & 12400 & 12200 & 12200 & 11800 & 12400 & 12400 \\
\hline 血色索\% & 87 & 86 & 86 & 85 & 85 & 85 \\
\hline 百过中球 & 66 & 65.5 & 69 & 675 & 72 & 66 \\
\hline 血好酸球 & 4 & 4.5 & 5 & 5.5 & 5 & 5 \\
\hline 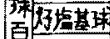 & 0 & 0 & 0 & 0 & 0 & 0 \\
\hline 耐垔球 & 9 & 7 & 6 & 6 & 4 & 7 \\
\hline 舟少炡球 & 21 & 23 & 20 & 21 & 19 & 22 \\
\hline
\end{tabular}


第10図重曹注射犬 60 分制战によるリンパ球

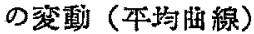

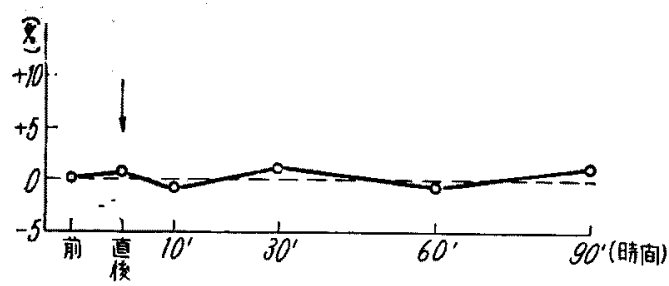

は股静脈より行つた・赤血球数は No. 43 は直後, 10 分 後に中や減少, 後には却つてやや増加, No.55 て㥀 啳に減少後僅加増加， 60 分後以後は殆んぞ 直前の価 に近ずいている. 白血球数は No.43では 10 分後兽 加し，その後は大体來战前值に戾り，No.55 では殆え ど変化はない，血色素量にも認むへき変化はない，好中 球は No. 43 は 60 分後を除いて減少を示し（最大 $6 \%$ 減少), No. 55 厄゙ 10 分後上り 60 分後迄は中や增加, 90 分後には元に復している (最大 $6 \%$ 増加). 好酸球山 No. 43 では直後より増加（5\%）60 分後よりは刺战前 值厌る傾向がみられる．No. 55 では殆んど变化はな い. 単球は No.55 の 60 分後にやや減少する他は認む べ变動はない、リンパ球の变動も僅かで，その平均值 は，直後飞 $0,75 \%, 10$ 分後 $0,65 \%, 30$ 分後 $1.25 \%$ 堌加, 60 分後0,25\% 減少, 90 分後 $1,25 \%$ 堌加の動摇を示して いるのみである(第10図).

\section{第4 章 加速趈転刺戟の迷路破壊犬血液像に 及ばす影響}

実験 24 時間前にエピパン・ナトリゥム全身麻醉のも と火両側迷路破壞を行つた成犬につき，加速迴転刺战， 15 分，30 分，60 分を与えて後，血液像に及ぼす影響を観 察した. そして第 2 章で正常犬に加速回転刺僦を与兄て 得た成績が果して迷路に加速度刺㦸が働いて起されたか 否かを，両側迷路破壊を行い完全に加速度に対する感受 性を消失せしめた犬に括いて観察した。文同時儿第了章 にのべた $7 \%$ 重曹水注射犬火得た実験成續との比较検討 を試みた。

第 1 節 15 分閭加速迴転刺㦸 再側迷路破㯖 犬血液像に及注す影響（第X表）

小括：採血は No.34, No.38 は下大静脈を結紮し, No. 54 は股静脈より行つた・赤血球数は殆んど変化な く，白血球数は刺㦸後やや減少をみるが，90分後には 殆んど回復し，血色素量にも大した变動はみられない。 好中球は No.34 飞打いて刺战後堿少し, No.38 ては
第 X表 迷路破统犬 15 分测韩の影犁

\begin{tabular}{|c|c|c|c|c|c|c|}
\hline & & & 7 & & (1) & \\
\hline & 则㧧前 & 䉼钱直 & 10 分後 & 30分棒 & 60分復 & 90 ग \\
\hline (n) & 530 & 532 & 540 & 530 & 540 & 54 \\
\hline 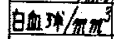 & 8700 & 8400 & 8600 & 8400 & 8200 & 860 \\
\hline $4 \%$ & 85 & 85 & 85 & 83 & 84 & 82 \\
\hline & 76 & 73.5 & 74 & 73.5 & 70.5 & 69 \\
\hline & 2 & 2.5 & 2.5 & 2 & 4 & 4. \\
\hline & 0 & 0 & 0 & 0 & 0 & 0 \\
\hline 垔碀 & 4 & 4 & 2.5 & 4 & 3.5 & 4 \\
\hline 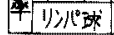 & 78 & 20 & 21 & 20.5 & 22 & 22 \\
\hline
\end{tabular}

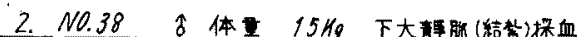

\begin{tabular}{|c|c|c|c|c|c|c|}
\hline & 剌戟前。 & 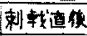 & 10分掼 & 30分後 & 60分後 & 90分得 \\
\hline 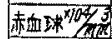 & 530 & 540 & 536 & 530 & 523 & 534 \\
\hline 回血球 $/ m^{3}$ & 9000 & 8800 & 9200 & 8400 & 8200 & 9000 \\
\hline 追危表 \% & 87 & 86 & 86 & 87 & 86 & 86 \\
\hline 6好中球 & 73.5 & 75 & 78 & 75 & 77 & 76 \\
\hline 血好球 & 3 & 3 & 2.5 & 3 & 2 & 3 \\
\hline 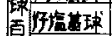 & 0 & 0 & 0 & 0 & 0 & 0 \\
\hline 公营 球 & 5.5 & 4 & 4.5 & 4 & 4 & 3 \\
\hline 率以ハ球 & 18 & 18 & 75 & 18 & 17 & 18 \\
\hline
\end{tabular}

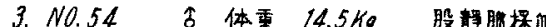

\begin{tabular}{|c|c|c|c|c|c|c|}
\hline & 耕孰前 & 刺战直 & 10分啳 & $3001 \%$ & 60 分移 & 000 \\
\hline 赤血球现 & 530 & 545 & 540 & 530 & 536 & 530 \\
\hline ém球 $/ 4 m^{3}$ & 9000 & 8600 & 8800 & 8400 & 8800 & 9400 \\
\hline 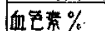 & 96 & 94 & 94 & 94 & 95 & 94 \\
\hline 白好中球 & 77 & 74 & 76 & 77.5 & 78 & 78 \\
\hline 血好酸球 & 1.5 & 2.5 & 2 & 1.5 & 2 & 2 \\
\hline 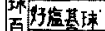 & 0 & 0 & 0 & 0 & 0 & 0 \\
\hline 分荲球 & 5.5 & 6.5 & 4 & 5 & 4 & 6 \\
\hline 革り四球 & 16 & 17 & 18 & 76 & 16 & 14 \\
\hline
\end{tabular}

第11图 迷路破壤犬 15 分测戟によるッンパ球 の装動 (本均曲線)

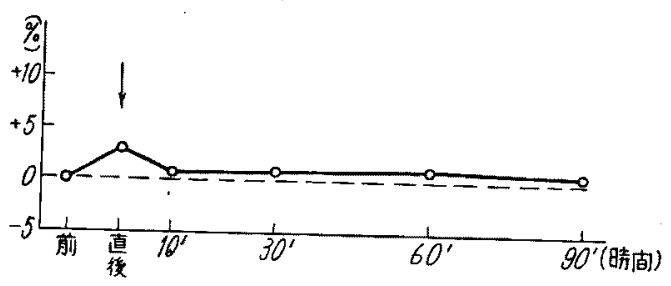

直後には僅かの減少，10分後よりは却つて増加，No.54 では直後やや減少するが後は殆んど刺战前と变りがな い. 好酸球は No. 34 で 60 分後より少しく堌加してい るがその仳は取り上げる程の変動はない，単球の変化は No. 34 の 10 分後, No.54 では 10 分後, 60 分後に最大 1.5 $\%$ No. 38 では 90 分後に最大 $2.5 \%$ の減少を示すのみで ある・リンパ球では No. 34 では刺战後より漸次增加し90 分後で最大 $7 \%$ 増加，No. 38 で恃 10 分後に $3 \%$ 減少の 他は大した变動なく No. 54 では直後，10 分後に 2\%増 加，90 分後に $2 \%$ 減少を示す. 平均值では直後に $3 \%$, 10 分後 $0,6 \%, 30$ 分後0,83\%,60 分後 1,0\%,90 分後 0,7 \%のそれぞれ増加を示すのみである（第11図）. 


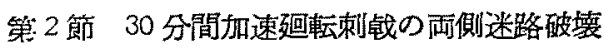
犬血液像に及洼吉影響（第入表）

小括：採血は No.32 は下大静脈より結禁せずに， No. 59 は股静脈より行つた。赤血球数, 白血球数, 血 色素量比殆えど大きな变動は認められず，好中球は No.32 で10 分後より堡か減少し，No.59 では殆ん ど変化なく，好酸球は No. 32 で 0,5 1\% の培減を示 すのみで，No. 59 では 30 分後家除き 0.5 2.5\% 増加と なつている. 単球は No. 32, 60 分後に 2\% 堌加が 最大 で, No. 59 では直後区び 30 分後に 3,5〜4\%の減少を

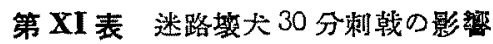

\begin{tabular}{|c|c|c|c|c|c|c|}
\hline & & & & & & \\
\hline & 刺斟前 & 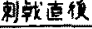 & 10分後 & 30今後 & 60分復 & 907 传 \\
\hline 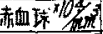 & 425 & 422 & 416 & 442 & 425 & 420 \\
\hline 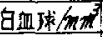 & 9600 & 9800 & 9600 & 8600 & 9000 & 8200 \\
\hline 血疋絭\% & 74 & 74 & 73 & 74 & 73 & 73 \\
\hline 白好中球 & 75 & 75 & 71 & 74.5 & 71.5 & 72 \\
\hline 血好酰球 & 4 & 3 & 3 & 4.5 & 4.5 & 3 \\
\hline 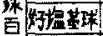 & 0 & 0 & 0 & 0 & 0 & 0 \\
\hline 分覃球 & 2 & 2.5 & 3 & 2 & 4 & 2 \\
\hline 率物球 & 19 & 19.5 & 23 & 19 & 20 & 23 \\
\hline
\end{tabular}

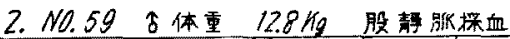

\begin{tabular}{|c|c|c|c|c|c|c|}
\hline & 俥戟前 & 刺戟直保 & 10分後 & 30分絪 & 60分後 & 90分得 \\
\hline 血国 1084 & 420 & 435 & 430 & 434 & 420 & 440 \\
\hline 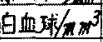 & 9200 & 9300 & 9000 & 9400 & 8800 & 9000 \\
\hline 血色素\% & 77 & 77 & 79 & 78 & 78 & 76 \\
\hline 白好中球' & 68 & 71 & 68 & 71.5 & 67.5 & 67.5 \\
\hline 血酸球 & 2 & 3.5 & 2.5 & 2 & 4.5 & 3 \\
\hline 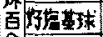 & 0 & 0 & 0 & 0 & 0 & 0 \\
\hline 昘罩球 & 6 & 2.5 & 5 & 2 & 5.5 & $6^{-}$ \\
\hline$7 \longdiv { 1 0 }$ & 24 & 23 & 24.5 & 24.5 & 22.5 & 23.5 \\
\hline
\end{tabular}

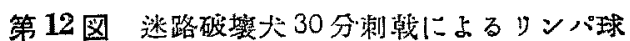
の变筑 (工均地線)

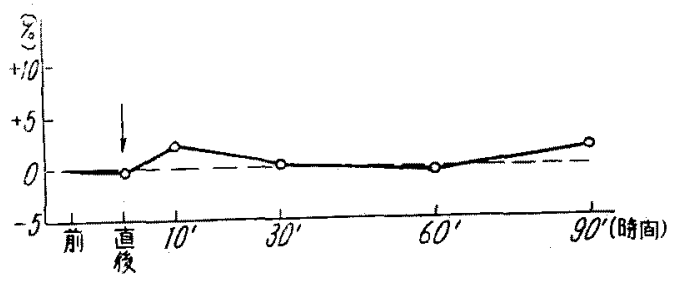

み，その峦化は不定である。リンパ球は No.32で10

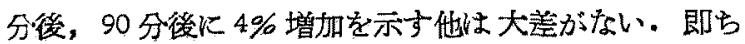
その平均值は，直後0,25\%減少，10 分後 $2,25 \% ， 30$ 分 後 $0,25 \%$ 増加， 60 分後 $0.25 \%$ 減少，90 分後位 $1.75 \%$ 増 加となつている(第12 図).

第 3 節 60 分間加速廹転刺战, 雨側迷路破壊 犬血液像に及ぼす影籍（第坥表）

小括：採血は No.40 は下大静脈より結禁下に，No.
第 XII 表 迷路破壤犬 60 分刺韩の影繁

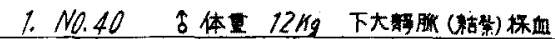

\begin{tabular}{|c|c|c|c|c|c|c|}
\hline & 玮校前 & 剌䛋直侥 & $10 \mathrm{~T}$ 秋 & 30 分後 & 60介绕 & $90 \pi n$ \\
\hline 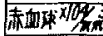 & 540 & 520 & 525 & 521 & 522 & 524 \\
\hline 血血球 $/ \pi \pi^{3}$ & 8800 & 8800 & 9000 & 9600 & 9000 & 9400 \\
\hline 血色素\% & 89 & 89 & 88 & 89 & 87 & 87 \\
\hline G仔中球 & 78.5 & 80 & 78.5 & 80 & 78 & 77 \\
\hline 血好酸球 & 3.5 & 4 & 4 & -4 & 1 & 4 \\
\hline 球应基残 & 0 & 0 & 0 & 0 & 0 & 0 \\
\hline 忽罩球 & 5 & 5.5 & 6.5 & 2 & 4 & 3 \\
\hline 率り以球 & 13 & 10.5 & $/ 1$ & 14 & 17 & 16 \\
\hline
\end{tabular}

\begin{tabular}{|c|c|c|c|c|c|c|}
\hline \multicolumn{2}{|c|}{ 2. $N 0.41$} & \multicolumn{2}{|c|}{ 体量 $10.5 \mathrm{Ha}$} & \multicolumn{3}{|c|}{ 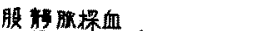 } \\
\hline & 剩敦前 & 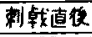 & 10分復 & 30 分愎 & 60001 & 90分倩 \\
\hline 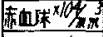 & 468 & 483 & 454 & 475 & 464 & 468 \\
\hline 皿血球/ $/ m^{2}{ }^{2}$ & 1100 & 12000 & $1 / 400$ & 12400 & 11200 & 12200 \\
\hline 血正素\% & 78 & 78 & 76 & 76 & 76 & 76 \\
\hline E好中珠 & 78.5 & 77.5 & 72 & 74.5 & 72 & 78 \\
\hline 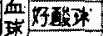 & 3 & 3 & 5 & 4 & 4 & 4 \\
\hline 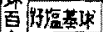 & 0 & 0 & 0 & 0 & 0 & 0 \\
\hline 金覃球 & 1 & 2 & 6 & 5.5 & 4 & 2 \\
\hline${ }^{+}$ & 17.5 & 17.5 & 17 & 16 & 20 & 16 \\
\hline
\end{tabular}

第 13 图迷路破敨犬 60 分刺戴によるリンバ球 の变動(平均成線)

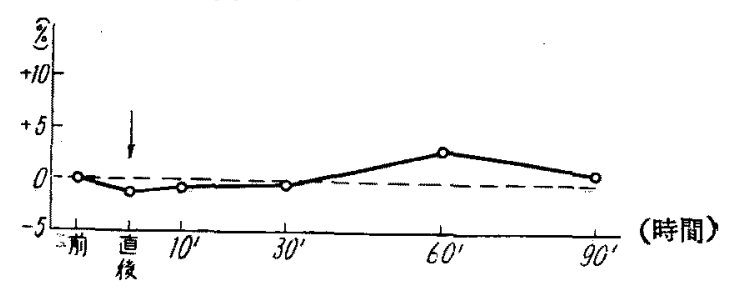

41 は股静脈より行つた・赤血球数, 白血球数，血色素 量の変動は殆えど愦差箇囲にあるをみられる。好中球は No. 40 て 60 分以後にやや減少，No.41 では 10 分後よ り娍少し 90 分後には元に戻つている. 好酸球は No. 40 て 60 分後に $2.5 \%$ 減少，No.41 では 10 分後に $2 \%$ 㦈加 するのみであり，単球は No.40の30分後以後に中や 減少の傾向があり，No.41 て普加し90 分後にはほぼ 刺㦸前值に厣つている. リンパ球仙 No.40 では剌戴直 挠より中p诚少し，30 分後から增加を示す. No.41 は 60 分後にやや堌加している. 即ち平均值は, 直後 1,25 $\%, 10$ 分後 $0,75 \%, 30$ 分後 0,25\%，減少し，60 分後 3,25\%，90 分後では 1.0\% の増加を示している（第13 図).

\section{総括及ひ考按}

正常犬について，15 分，30 分，区び 60 分間の加速䢙 転刺钱を与え，その血液像の变化を観察した。

1）赤血球数はそのの形態については特記すべきとこ

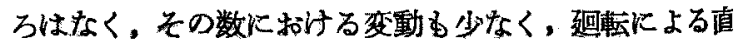
接つ影響はないのではないかと思われる。 


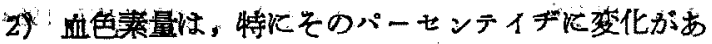

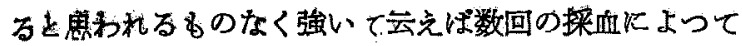
ま費血の傾尚がみられる。

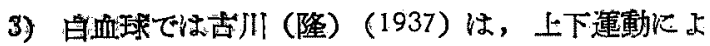

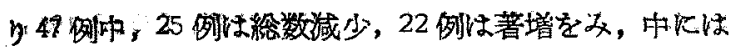

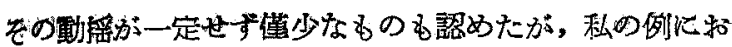
いで，白血球数性 22 例中正常群では增加 3 ，著变のな いわの 4, 減少 る4の，淢少1であり，迷路醊壊群では增加 1 ，著变のな いるの，減少 1 で変化の程度は著しくない。

白血球百分率炕ついては，特に著明な変化の認められ

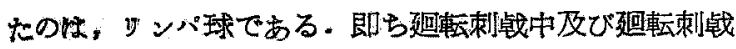
終了後つリッメ゚球の変動を穓察すると，その亚场值は䢙 蛙中刺战開始後 15 分で $3.6 \% ， 30$ 分で $6.83 \% ， 60$ 分で 7.83\% 堌加と侍間の経過と共に增加し，迴転停止後は 10 分後比 $8.9 \%$ 増加と最高となり，以後 30 分後からは 8.21 \%,60 分後には 4.94\%，90 分後では 3.93\%增加々次第 に刺㦸前值復する傾向を示している（第: 14 图）。

第 14 图 趣転制载によるリンパ球の变動 （平均曲線）

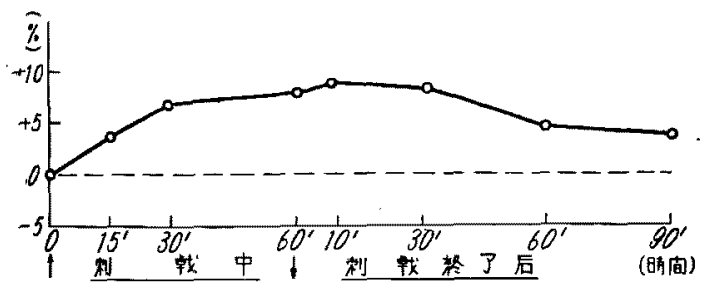

促来交感神経緊張症なればワンバ球は減少するといわ れ，しかる古川(隆) (1937) は家鬼を使つて上下算降 建動により減少するといつている，私绀実験に当つては 植物神経の比較的安定でちり，且つ大きな動物を使用す るのが適切と考克犬を使用した．そして加速廻転刺战の

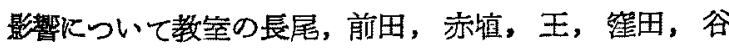
口，上善，毛利等も同じく犬を使用して实験を行い，交 藏神経緊張症と結論した。そのような傾向を示すとき， 私の実駼忹先人に比し異なつた結果を得たが，対招実敛 として行つたアドレナリン注射によつてもその血液像特 Kリンバ球の変動は，加速廻転刺㦸後のそれらと同様で 嵌り、リンパ球つ增加したこと及び他の研究結果と考光

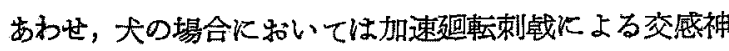
経㬎張性の変化としてりンパ球の增加がみられるのであ ろうと思われる。

好中球はリシパ球とほぼ反比例して，刺战媵 10〜30
分後に減少の度最高となり以後刺战前值に復する傾向を 示してい寺（しかしリンパ球の変動が最る著明，定型 的であるのてここでは主としてッンバ球炕いてのべ た).

好酸球及び単球等には一定した変動は認められない。 好塩基球等はみられなかつた。

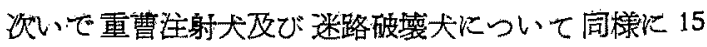

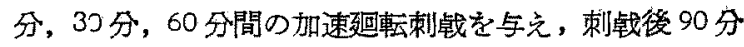
迄観察したが，総てにおいて，血液像の著明な変化はみ そめられなかつた、以上の実験成嘖から加速廻転刺战に より血液中白血球百分率の变化，特にりンパ球の増加及 び好中球の減少をみ，両側迷路破壊及び $7 \%$ 重曹水注射 によつてその影響が阻止されるのを諗わた。

\section{結 語}

加速廻転刺战が血液像に及ぽす影響並びにとれに対す

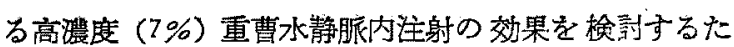

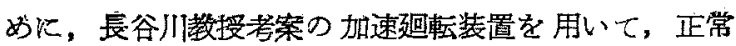
犬，重曹注射犬及び耐側迷路破萝大に 15 分，30分，60

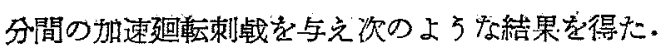

1）正常犬群では加速廻転刺戲により，赤血球数，白 血球数，血色素量以は著明な变化はみられなからたが，

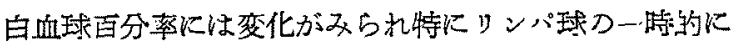
增加するのが認わられ，また好中球は減少する傾向があ り，好酸球や単球等には堌減の一定した傾向は示さなか つた・好䔤基球等はみられなかった。

2）迷路破壊大群では加速廷転刺㦸により血液像には 著しい変化がみられなかった。

3）重曹注射犬群に和いて子迷路破壊犬群に扔けると 同様，加速迴転刺㦸により殆んど影響を認めなかつた。

以上の実険成績から，加速廻転刺㦸が迷路に働き，恐 らく交感神経緊張性の自律神経機能障碍圭きたして，血 液像殊に白血球百分率傹影響を及代するのと思われる。

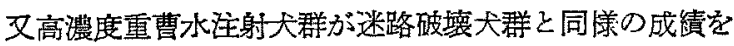
示し，加速迴転刺战による血液像（殊に白血球百分率） の変化を阻止することは，重曹静注が加速度剌㜞を㧕制 し，恐らく耳石基磷物質を溶解したためと思われる。

\section{参考 文 献}

1) Barany, R.: M. Schr. Ohren H.K. 44; 72.3, 1910. 2) Hasegawa, T.: Pflügers Arch. 229: $205,1931 . \quad 3)$ Hasegawa: Arch. of Otolarng. 50; 708, 1949. 4) Selye, H.: J. Clin. Endocr. 6; 117, 1946. 5) idem: J.A.M.A. 114; 1353, 1650. 6) 天野重安：血液学の基磷，1948. 7) 


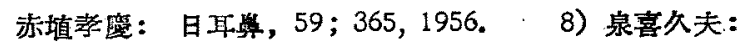

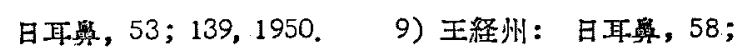
749, 1955. 10) 王経州：耳㬋，49；854, 1956.

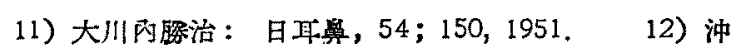
中重雄：自律神経と器床，1948。13）金并泉：䛗

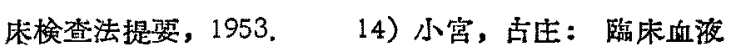
図說，1950. 15) 古代泰敬：日耳孟；57；456, 1954. 16）佐藤清：血玩の見方，1948. 17）柴田精郎:

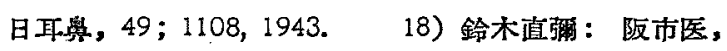
$1 ; 225,1952$. 19）鈴木直彌：阪市医，2；104, 1953. 20）谷口武：日耳载，59；263,1956. 21) 中島卓磨：日耳孯，56；96，1953.22) 長尾政明： 日耳㐞，58；480，1955.23）它尾健：副肾皮質水 ルモン，1953. 24) 西川㼁方：內猃燎の实際, 1951. 25) 額田晋：阿科㥉断学. 26）長谷川高敏：船醉, 久保耳科全書, 23；471，1935.27) 長谷川高敏: 耳院，13；750，1940.28）長谷川高敏：加速度满, 1948. 29）長谷川高敏：船醉の治療, 1950. 30) 長谷川高敏：耳喉, $26 ； 695,1954.31$ 長谷川高

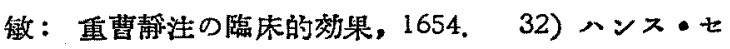

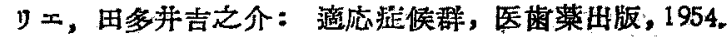

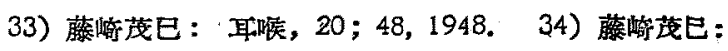

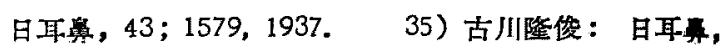
43 ; 1579, 1937.36$)$ 古川林三郎：日耳鼻， 47 ; 1264，1941. 37）松杪忠樹：実験治洪， $285 ； 3,1956$. 38）前田春雄：日耳愁，59；349，1956. 39）前田 春雄：日耳莮，59，387，1956.40）松山三千綠：

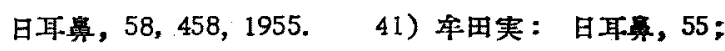
925，1952。42）毛利茂男：日耳劣，58；877，1955。

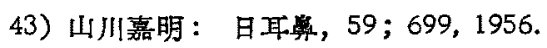

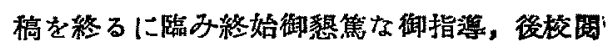
を賜わつた恩師長谷川高敏教授に深甚の謝意を

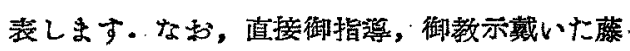

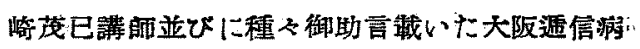

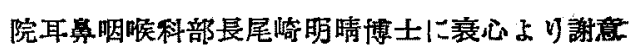
を衰します。

（原稿到盖 $=$ 昭和 33.7 .11 日） 